\title{
Formulation of Zero-Trans Crystalized Fats Produced from Palm Stearin and High Oleic Safflower Oil Blends
}

\author{
Nydia E. Buitimea-Cantúa, ${ }^{1}$ María Guadalupe Salazar-García, ${ }^{2}$ \\ Reyna Luz Vidal-Quintanar, ${ }^{2}$ Sergio O. Serna-Saldívar, ${ }^{1}$ \\ Refugio Ortega-Ramirez, ${ }^{2}$ and Génesis Vidal Buitimea-Cantúa ${ }^{1,3}$ \\ ${ }^{1}$ Tecnologico de Monterrey, Escuela de Ingeniería y Ciencias, Ave. Eugenio Garza Sada 2501, 64849 Monterrey, NL, Mexico \\ ${ }^{2}$ Programa de Posgrado en Ciencias y Tecnología de Alimentos, Departamento de Investigación y Posgrado en Alimentos, \\ Universidad de Sonora, Blvd. Luis Encinas y Rosales s/n Col. Centro, Postal 1658, 83000 Hermosillo, SON, Mexico \\ ${ }^{3}$ Centro de Investigación y de Estudios Avanzados del Instituto Politécnico Nacional, Libramiento Norte Carretera Irapuato León, \\ Kilómetro 9.6, 36821 Irapuato, GTO, Mexico
}

Correspondence should be addressed to María Guadalupe Salazar-García; gsalazar@guayacan.uson.mx

Received 7 August 2017; Accepted 16 October 2017; Published 9 November 2017

Academic Editor: Domenico Montesano

Copyright (C) 2017 Nydia E. Buitimea-Cantúa et al. This is an open access article distributed under the Creative Commons Attribution License, which permits unrestricted use, distribution, and reproduction in any medium, provided the original work is properly cited.

High intake of trans fat is associated with several chronic diseases such as cardiovascular disease and cancer. Fat blends, produced by direct blending process of palm stearin (PS) with high oleic safflower oil (HOSO) in different concentrations, were investigated. The effects of the PS addition (50,70, or 90\%) and the rate of agitation (RA) (1000, 2000, or $3000 \mathrm{rpm}$ ) on physical properties, fatty acid profile (FAP), trans fatty acids (TFA), crystal structure, and consistency were researched. The blend containing $50 \%$ of each sort of oil ( $50 \% \mathrm{PS} / 50 \% \mathrm{HOSO}$ ) showed that melting point and features were similar to the control shortening. The saturated fatty acids (SFA) were higher followed by monounsaturated (MUFA) and polyunsaturated fatty acids (PUFA). Significant differences in the content of palmitic and oleic acids among blends were observed. The 50\% PS/50\% HOSO blend contained higher oleic acid (42.9\%) whereas the $90 \%$ PS/10\% HOSO was higher in palmitic acid (56.9\%). The blending of PS/HOSO promoted the $\beta$ crystal polymorphic forms. The direct blending process of equal amounts of PS and HOSO was an adequate strategy to formulate a new zero-trans crystallized vegetable fats with characteristics similar to commercial counterparts with well-balanced fats rich in both omega 3 and omega 6 fatty acids.

\section{Introduction}

Bakery shortenings prepared by hydrogenation process of vegetable oils contain levels between 20 and $40 \%$ of trans fatty acids (TFA) [1]. TFA have negative health implications especially in terms of the ratio of high-density to low-density lipoproteins, which is correlated with risk of cardiovascular diseases [2]. Several published reports have indicated that TFA have also adverse effects on serum cholesterol, triglyceride levels, and coronary heart diseases $[3,4]$. The harmful effects of TFA on the ratio of total cholesterol to HDL cholesterol are reported to be twice compared to saturated FA [5]. Kromhout et al. [6] concluded that a gram-for-gram basis TFA has been associated with an increase of 15 times of greater incidence of coronary heart diseases than SFA. TFA have also been related with risk of breast and colon cancer, diabetes, obesity, and allergies [2].

The World Health Organization (WHO) and Food and Agricultural Organization (FAO) recommend that the daily intake of TFA should not exceed $4 \%$ in foods and consequently, some countries impose maximum legal limits of these fatty acids [7]. Recently, the FDA mandated that partially hydrogenated oils, the primary dietary source of trans fats in processed foods, be removed from products entirely by 2018 [8]. Therefore, efforts have been made to replace hydrogenated oils by other fat sources with lower or zero-trans fats [9] without sacrificing the functional properties [10]. 
Chemical interesterification (CI), enzyme interesterification (EI), and direct blending (high-melting fraction with vegetable oils) are viable alternatives to the hydrogenation process. These processes are aimed to impart the desired functionality without generating TFA [10-12]. Direct blending has several advantages compared to either CI or EI $[13,14]$, the most relevant being that no chemical processes are involved, and is consistent with the consumer trend toward consumption of natural products [13]. Additionally, the knowledgeable selection of fat blends and the proper crystallization process is critical for the production of plastic shortenings without hydrogenation [14].

PS is an excellent substitute for animal fats for the production of shortenings without cholesterol [15] mainly because it is natural and cheaper. This high-melting fraction is obtained after fractionation of palm oil which is the second most produced oil worldwide. However, because of its highmelting profile ranging from 44 to $56^{\circ} \mathrm{C}$, PS cannot be used directly for production of shortening as it causes low plasticity to the products [16]. Thus, it might be appropriately blended with liquid oils in order to modify the overall physical characteristics of the mixture to enhance functionality and the quality required for trans-free shortening preparation $[14,17,18]$. Furthermore, PS has the ability of promoting the polymorphic form of fat crystal $\beta^{\prime}$, which is desirable in shortenings. This particular polymorphic form has a large surface area, fine arrangement (packing of small crystals), and greater oil-holding capacity $[14,19]$.

Moreover, several studies have reported the feasibility of formulating zero-or low-trans shortenings using PS blended with other oils that after processing generate crystallized fats with similar organoleptic and functional properties compared to commercial shortenings [10, 14, 17, 18]. Mayamol et al. [14] blended PS and rice bran oil $(50: 50)$ to prepare trans-free bakery shortenings whereas other investigators $[12,20,21]$ devised comparable bakery shortenings with similar blends without significantly affecting the physicochemical and textural properties of products. The vegetable oils from sunflower, palm, rapeseed, camellia, canola, rice bran, sesame, and soybean have been previously utilized in formulation of zero-or low-trans crystallized fats. However, sunflower oil, like other polyunsaturated oils, is unstable and its use as cooking oil limited because of its high degree of unsaturation or iodine value (linoleic acid content greater than $75 \%$ ) which makes it more prone to both oxidative and thermal deteriorations [22].

Various oils with different fatty acid profiles have been developed by plant breeding, including low-linolenic soybean, high oleic sunflower, low-linolenic canola, high oleic canola, and high oleic safflower $[23,24]$. All these modified natural oils have improved frying stability compared to unmodified counterparts [25]. Carthamus tinctorius seeds are rich in edible oil (high oleic safflower oil), with similar content to olive. This oil is typically composed of oleic (74\%), linoleic (16-25\%), and linolenic (1-6\%) acids [26]. This is relevant because oleic acid consumption is considered cardioprotective according to studies of the Mediterranean diet rich in olive oil [27]. HOSO is used for its high resistance to oxidation and heat degradation enabling its use in many baking applications including high temperature frying. The trans free HOSO can diminish saturated fat levels, which is ideal in order to generate clean food labels to food manufacturers and for health-conscious consumers [26, 28].

When developing a new shortening, it is essential to optimize the physicochemical properties with an acceptable level of oxidative stability. During storage, the lipid oxidation is a major cause of deterioration, leading to the development of rancid off-odors and flavors [29]. Hence, to obtain a healthy product, oxidative stability is critical in practical use of shortenings. Therefore, the objective of this study was to develop zero-trans crystalized fat formulations produced from blending palm stearin and high oleic safflower oil without sacrificing functional properties and acceptability in terms of oxidative stability.

\section{Materials and Methods}

2.1. Materials. The palm stearin (PS) was purchased from $\mathrm{RBD}$ (Industrializadora Oleofinos SA de CV) whereas the high oleic safflower oil from OLEICO (Coral Internacional, $\mathrm{SA}$ de $\mathrm{CV}$ ). The hydrogenated commercial shortening was obtained from SARITA (Proteinas y Oleicos SA de CV). Standards of FAME, linoleic acid methyl ester isomer mix, and linolenic acid methyl ester isomer mix were purchased from Sigma, St. Louis, MO. All other chemicals used were analytical grade and purchased from JT Baker Deventer, Netherlands.

2.2. Process of Production of Zero-Trans Fat. The PS was melted in a temperature controlled water bath set at $60^{\circ} \mathrm{C}$. The melted PS and HOSO were blended in a mixer (vertical Robot Coupe PVM, model RS110V) in mass ratios (PS/HOSO) of $50: 50,70: 30$, or $90: 10$. Resulting blends were mixed for $10 \mathrm{~min}$ at 1000,2000 , or $3000 \mathrm{rpm}$ at a constant temperature of $70^{\circ} \mathrm{C}$. The homogeneous fat blend was poured in $500 \mathrm{~mL}$ closed plastic containers and tempered and equilibrated at 30 $\pm 1^{\circ} \mathrm{C}$ for $5 \mathrm{~d}$ according to the method previously described by Mayamol et al. [14] with slight modifications. The factors involved in this new modification were the sources of fat (palm stearin and high oleic safflower oil) and speed of agitation.

2.2.1. Physical Analyses. The different blends of PS/HOSO were analyzed in terms of color (Lovibond red) (method, Cc 13e-92), refractive index (method Cc 7-25), capillary melting point (method Cc-1-25), relative density (method Cc 10a-25), acidity (method Ca 5a-40), peroxide value (method Cd 8-53), moisture and volatile matter (method $\mathrm{Ca} 2 \mathrm{~d}-25)$, and iodine value (method Cd 1c- 85) according to official AOCS [30] procedures.

2.2.2. Fatty Acid Profile. The fatty acid profile (FAP) of blends (PS/HOSO) was determined by gas chromatography as described by Medina-Juárez et al. [31]. The identification and quantification of the methyl esters were determined by the method Ce 1-62 of the AOCS [30]. The gas chromatograph (VARIAN 3400, Mexico City, Mexico) was equipped with a flame-ionization detector (FID) and an integrator (Model 
1020, Perkin Elmer, Mexico City, Mexico). A capillary column with $100 \%$ biscyanopropyl polysiloxane as the stationary phase SP-2560 $(100 \mathrm{~m} \times 0.25 \mathrm{~mm}$ i.d. $\times 0.2 \mu \mathrm{m}$; Supelco, Inc., Bellefonte, PA 16823-0048 USA) was used. The oven temperature was set at $140-210^{\circ} \mathrm{C}$ for $4^{\circ} \mathrm{C} / \mathrm{min}$, followed by $210-215^{\circ} \mathrm{C}$ for $1^{\circ} \mathrm{C} / \mathrm{min}$, and finally $215-220^{\circ} \mathrm{C}$ for $0.5^{\circ} \mathrm{C} / \mathrm{min}$. Nitrogen was used as carrier gas with a flow of $20 \mathrm{~cm} / \mathrm{s}$. The temperature of the injector and detector was $250^{\circ} \mathrm{C}$. The identification and quantification of the peaks were performed by comparison with the retention times and areas of the corresponding standards (Sigma Chemical Co., St. Louis, MO). Trans isomers were identified from the linoleic and linolenic acids methyl ester isomer mixes. Results were expressed as weight percentage (wt\%) of fat.

2.2.3. Polymorphism. The polymorphic forms of fat in the blends were determined by X-ray diffraction (XRD) according to the methodology described by Mayamol et al. [10], using a Broker Model D8 ADVANCE X-ray diffractometer emitting $\mathrm{Cu} \alpha$ radiation. Data were collected at room temperature from 5 to $452 \theta$. X-ray data were processed by a computer programmed to calculate absorption intensitybackground, intensity, and peak width in degrees for each crystalline form. The relative contents of $\alpha, \beta$, and $\beta^{\prime}$ crystals were acquired. The $\beta$ form was calculated from the intensity of the short spacing at $4.6,3.8$, and $3.7 \AA$ whereas the $\beta^{\prime}$ polymorph was calculated from the intensities of the short spacing of 3.8 and $4.2 \AA$.

2.2.4. Consistency. The consistency of the crystallized blends was tested with a cone penetrometer (KOEHLER Model Instrument Company INC) in samples tempered at three different temperatures $\left(12^{\circ} \mathrm{C}, 20^{\circ} \mathrm{C}\right.$, or $\left.30^{\circ} \mathrm{C}\right)$ according to method Cc 16-60 AOCS [30]. The crystallized fats were tempered in bioclimatic chambers set at 12,20 , or $30^{\circ} \mathrm{C}$.

2.3. Statistical Analysis. A completely randomized experiment was performed. PS addition $(50,70$, or $90 \%$ ) and the rate of agitation (RA) $(1000,2000$, or $3000 \mathrm{rpm})$ were the factors considered. Analysis of variance (ANOVA) and comparison of means by Tukey (significance level of 95\%) were performed. Data was reported as means and standard deviations. Analyses were performed using the JMP 5.0.1 statistics software (SAS Institute, Cary, NC, USA).

\section{Results and Discussion}

3.1. Physicals Properties. The results of the color, refraction index, melting point, density, acidity, moisture, and peroxide and iodine values of palm stearin, high oleic safflower oil, $\mathrm{PS} / \mathrm{HOSO}$ crystallized blends mixed at different agitation rates, and HCS are depicted in Tables 1 and 2. As expected, the various physical properties were significantly affected $(p<0.05)$ by the different ratios of PS and HOSO. Hydrogenated fats should have a red color value of 1.5 [32]. Among the experimental blends, the color of the $90 \% \mathrm{PS} / 10 \%$ HOSO mix had higher reddish (3.0) scores $(p<0.05)$ compared to the control HCS (2.0). The observed differences in color can be attributed to PS addition, HOSO addition, and fat type (vegetable or animal sources). The PS had a higher red color score of 3.5. This could be attributed to the presence of tocopherols and $\beta$-carotenes that are responsible for imparting orange, reddish, and yellow colorations [14, 33]. Furthermore, the HOSO contained high concentrations of total tocopherols (178 ppm) which contained $85.82 \% \alpha$ tocopherol [28].

Various blends containing PS and vegetable oils were screened based on iodine value (IV) and melting point [10, 17]. IV is an important parameter used in the hydrogenation industry because its value is closely related to melting point and oxidative stability. Shortenings with low-iodine value have lower melting points and are less susceptible to oxidation or are more stable [17]. The IV of HOSO was 90 (Table 1). After blending with the hard fraction of the palm oil, there was a decrease in IV. As expected, the lowest value was observed in the blend containing $90 \%$ palm stearin. There was a gradual increase in the melting point from $46^{\circ} \mathrm{C}$ to $50^{\circ} \mathrm{C}$ when the PS concentration in the PS/HOSO blends increased (Table 2). Hydrogenated fats should have a melting point between $35^{\circ} \mathrm{C}$ and $45^{\circ} \mathrm{C}$ [26] and the PS showed a melting point of $52^{\circ} \mathrm{C}$ (Table 1). The melting point of the blends containing PS of $90 \%$ was higher compared to the $50 \%$ blend (Table 2). There were no significant differences $(p>0.05)$ in the acidity, peroxide value, and moisture of the blends. The PS did not affect significantly $(p>0.05)$ the physical properties of the experimental blends.

3.2. Fatty Acids Profile. The fatty acid profiles of PS/HOSO blends $(50: 50,70: 30$, and $90: 10)$ processed at agitation rates of $3000 \mathrm{rpm}$ and HCS are presented in Table 3. As expected, the FAP was significantly affected $(p<0.05)$ by addition of different ratios of PS and HOSO. The PS presented higher content of palmitic and oleic acids $(49.81 \%$ and $20.56 \%$, resp.) whereas the HOSO contained comparatively higher levels of oleic and linoleic acids (77.50\% and $12.01 \%$, resp.) (Table 1). The FAP of the PS/HOSO blends indicated that the components in order of abundance were palmitic (36.8-56.9\%), oleic (27.1-42.9\%), linoleic (6.1-12.3\%), stearic (4.4-4.9\%), and palmitoleic acids (0.3-0.52\%). In PS/HOSO blends, the amounts of total saturated $\Sigma$ SFA (palmitic and stearic) were higher compared with monounsaturated fatty acids ( $\Sigma$ MUFA) (oleic and palmitoleic) and $\Sigma$ PUFA (linoleic and linolenic). Similar results were reported by Mayamol et al. [10], who assayed the fatty acid profiles of binary blends of PS and rice bran oil, finding as main components palmitic (37.4-43.2\%), oleic (34.3-36.3\%), linoleic (16.5-20.6\%), stearic (2.9-3.0\%), and linolenic (0.31-0.51\%) acids. Recently, Latip et al. [21] reported in a binary mixture of $50 \%$ PS $/ 50 \%$ sunflower oil a higher composition of palmitic (36.3\%), linoleic (31.7\%), oleic (25.2), and stearic (4.7\%) acids.

As the concentration of PS increased in the PS/HOSO blends the content of SFA also increased, particularly palmitic acid. Among all blends, the one consisting of 50\% PS/50\% HOSO contained the lowest levels of $\Sigma$ SFA (43.29\%) and highest levels of both $\Sigma$ MUFA (43.20\%) and $\Sigma$ PUFA (12.38\%). On the other hand, the $90 \%$ PS/10\% HOSO blend contained the highest levels of $\Sigma$ SFA (63.64\%) and lowest levels of $\Sigma$ MUFA (27.67\%) and $\Sigma$ PUFA (6.17\%), respectively. Addition 
TABLE 1: Physical properties, fatty acid compositions, and consistencies of palm stearin and high oleic safflower oil ${ }^{1}$.

\begin{tabular}{|c|c|c|}
\hline Characteristics & Palm stearin & High oleic safflower oil \\
\hline Colour (Lovibond red) & 3.50 & 1.00 \\
\hline Refractive index $\left(50 / 25^{\circ} \mathrm{C}\right)$ & 1.45 & 1.463 \\
\hline Melting point $\left({ }^{\circ} \mathrm{C}\right)$ & 52.00 & - \\
\hline Relative density $\left(60 / 25^{\circ} \mathrm{C} ; \mathrm{g} / \mathrm{ml}\right)$ & 0.8728 & 0.919 \\
\hline Acidity (Oleic\%) & 0.0375 & 0.21 \\
\hline Peroxides $\left(\mathrm{Meq}_{2} / \mathrm{Kg}\right)$ & 0.20 & 0.50 \\
\hline Moisture and volatile matter (\%) & 0.22 & 0.05 \\
\hline Iodine value (gr. $\mathrm{I}_{2} / 100 \mathrm{gr}$ ) & 32.23 & 90.00 \\
\hline \multicolumn{3}{|l|}{ Fatty acids composition $(\%)^{\dagger}$} \\
\hline Myristic (14:0) & 1.83 & ${ }^{*} \mathrm{ND}$ \\
\hline Palmitic (16:0) & 55.33 & 6.09 \\
\hline Palmitoleic (16:1 n-7) & 0.83 & ND \\
\hline Stearic $(18: 0)$ & 9.72 & 2.64 \\
\hline Oleic (18:1 n-9) & 22.84 & 77.50 \\
\hline Linoleic (18:2 n-6) & 8.75 & 12.01 \\
\hline Linolenic (18:3 n-3) & 0.66 & 0.25 \\
\hline Fatty acids trans & ${ }^{*} \mathrm{ND}$ & ${ }^{*} \mathrm{ND}$ \\
\hline Polymorphic forms & $\beta \approx \beta^{\prime}$ & $\beta$ \\
\hline \multicolumn{3}{|l|}{ Consistency $(\mathrm{mm} / 10 \mathrm{~g})$ to: } \\
\hline $12^{\circ} \mathrm{C}$ & 70.00 & - \\
\hline $20^{\circ} \mathrm{C}$ & 117.00 & - \\
\hline $30^{\circ} \mathrm{C}$ & 209.00 & - \\
\hline
\end{tabular}

${ }^{1}$ Values are the mean of three replicates; ${ }^{\dagger}$ weight percentage; ${ }^{*}$ ND: not detectable.

TABLE 2: Physical properties of zero-trans crystallized fats produced from palm stearin-high oleic safflower oil blends compared to hydrogenated commercial shortening ${ }^{1,2}$.

\begin{tabular}{|c|c|c|c|c|c|c|c|c|c|}
\hline $\begin{array}{l}\text { Concentration } \\
\text { PS/HOSO } 3 \text { (\%) }\end{array}$ & $\begin{array}{l}\text { Rate of } \\
\text { agitation } \\
(\mathrm{rpm})\end{array}$ & $\begin{array}{l}\text { Color } \\
\text { (red) }\end{array}$ & $\mathrm{RI}^{4}$ & $\begin{array}{l}\text { Melting point } \\
\quad\left({ }^{\circ} \mathrm{C}\right)\end{array}$ & $\begin{array}{l}\text { Density } \\
(\mathrm{g} / \mathrm{mL})\end{array}$ & $\begin{array}{c}\text { Acidity } \\
\text { (Oleic \%) }\end{array}$ & $\begin{array}{c}\text { Peroxides } \\
\left(\mathrm{Meq} \mathrm{O}_{2} / \mathrm{Kg}\right)\end{array}$ & $\begin{array}{l}\text { Moisture } \\
\left({ }^{\circ} \mathrm{C}\right)\end{array}$ & $\begin{array}{l}\text { Iodine value } \\
\text { (gr. } \mathrm{I}_{2} / 100 \text { gr) }\end{array}$ \\
\hline \multirow{3}{*}{$50: 50$} & 1000 & $2.7^{c}$ & $1.4610^{\mathrm{a}}$ & $46^{\mathrm{c}}$ & $0.908^{\mathrm{d}}$ & $0.015^{\mathrm{a}}$ & $0.60^{\mathrm{a}}$ & $0.5^{\mathrm{a}}$ & $52.45^{\mathrm{a}}$ \\
\hline & 2000 & $2.7^{\mathrm{c}}$ & $1.4610^{\mathrm{a}}$ & $46^{\mathrm{c}}$ & $0.909^{c}$ & $0.015^{\mathrm{a}}$ & $0.60^{\mathrm{a}}$ & $0.5^{\mathrm{a}}$ & $52.45^{\mathrm{a}}$ \\
\hline & 3000 & $2.7^{\mathrm{c}}$ & $1.4610^{\mathrm{a}}$ & $46^{\mathrm{c}}$ & $0.908^{\mathrm{d}}$ & $0.015^{\mathrm{a}}$ & $0.60^{\mathrm{a}}$ & $0.5^{\mathrm{a}}$ & $52.45^{\mathrm{a}}$ \\
\hline \multirow{3}{*}{$70: 30$} & 1000 & $2.9^{\mathrm{b}}$ & $1.4595^{\mathrm{b}}$ & $48^{\mathrm{b}}$ & $0.931^{b}$ & $0.015^{\mathrm{a}}$ & $0.60^{\mathrm{a}}$ & $0.5^{\mathrm{a}}$ & $46.45^{\mathrm{b}}$ \\
\hline & 2000 & $2.9^{\mathrm{b}}$ & $1.4595^{\mathrm{b}}$ & $48^{\mathrm{b}}$ & $0.932^{\mathrm{a}}$ & $0.015^{\mathrm{a}}$ & $0.60^{\mathrm{a}}$ & $0.5^{\mathrm{a}}$ & $46.45^{\mathrm{b}}$ \\
\hline & 3000 & $2.9^{\mathrm{b}}$ & $1.4595^{\mathrm{b}}$ & $48^{\mathrm{b}}$ & $0.931^{\mathrm{b}}$ & $0.015^{\mathrm{a}}$ & $0.60^{\mathrm{a}}$ & $0.5^{\mathrm{a}}$ & $46.45^{\mathrm{b}}$ \\
\hline \multirow{3}{*}{$90: 10$} & 1000 & $3.0^{\mathrm{a}}$ & $1.4580^{\mathrm{d}}$ & $50^{\mathrm{a}}$ & $0.877^{\mathrm{e}}$ & $0.015^{\mathrm{a}}$ & $0.60^{\mathrm{a}}$ & $0.5^{\mathrm{a}}$ & $34.03^{\mathrm{d}}$ \\
\hline & 2000 & $3.0^{\mathrm{a}}$ & $1.4580^{\mathrm{d}}$ & $50^{\mathrm{a}}$ & $0.877^{\mathrm{e}}$ & $0.015^{\mathrm{a}}$ & $0.60^{\mathrm{a}}$ & $0.5^{\mathrm{a}}$ & $34.03^{\mathrm{d}}$ \\
\hline & 3000 & $3.0^{\mathrm{a}}$ & $1.4580^{\mathrm{d}}$ & $50^{\mathrm{a}}$ & $0.877^{\mathrm{e}}$ & $0.015^{\mathrm{a}}$ & $0.60^{\mathrm{a}}$ & $0.5^{\mathrm{a}}$ & $34.03^{\mathrm{d}}$ \\
\hline $\begin{array}{l}\text { Hydrogenated } \\
\text { commercial } \\
\text { shortening }\end{array}$ & & $2.0^{\mathrm{d}}$ & $1.4590^{c}$ & $45^{\mathrm{d}}$ & $0.810^{\mathrm{f}}$ & $0.015^{\mathrm{a}}$ & $0.55^{\mathrm{b}}$ & $0.4^{\mathrm{b}}$ & $43.00^{c}$ \\
\hline
\end{tabular}

of $90 \%$ of PS to blend increased levels of palmitic acid up to $19.8 \%$ and decreased the amounts of oleic acid, down to $14.7 \%$. All PS/HOSO experimental blends did not contain assayable levels of TFA. The differences observed among blends could be attributed to the typical fatty acid compositions of PS $[10,17,34]$ and HOSO. The observed changes in fatty acids profile clearly affected the functional characteristics of binary mixtures [21].

The HCS had higher levels of $\Sigma$ SFA (40.91\%), $\Sigma$ MUFA (38.01\%), TFA (17.02\%), and only $4.01 \%$ of $\Sigma$ PUFA (Table 3 ). Commonly, the HCS contain from 20 to $40 \%$ TFA [1] which have beneficial effects on the texture and appearance of foods 
TABLE 3: Fatty acid compositions of zero-trans crystallized fats produced from palm stearin-high oleic safflower oil blends compared to commercial hydrogenated shortening ${ }^{1,2}$.

\begin{tabular}{|c|c|c|c|c|}
\hline \multirow{2}{*}{ Fatty acids composition $(w t \%)^{\dagger}$} & \multicolumn{4}{|c|}{ Shortening } \\
\hline & Hydrogenated commercial shortening & $\mathrm{PS} / \mathrm{HOSO}^{3}(50: 50)$ & PS/HOSO $(70: 30)$ & PS/HOSO $(90: 10)$ \\
\hline Myristic (14:0) & ${ }^{*} \mathrm{ND}$ & $1.59^{\mathrm{e}}$ & $1.96^{\mathrm{e}}$ & $2.32^{\mathrm{e}}$ \\
\hline Palmitic (16:0) & $22.02^{\mathrm{b}}$ & $36.80^{\mathrm{b}}$ & $47.84^{\mathrm{a}}$ & $56.90^{\mathrm{a}}$ \\
\hline Stearic (18:0) & $18.89^{\mathrm{c}}$ & $4.90^{\mathrm{d}}$ & $4.74^{\mathrm{d}}$ & $4.42^{\mathrm{d}}$ \\
\hline$\Sigma \mathrm{SFA}^{4}$ & 40.91 & 43.29 & 54.54 & 63.64 \\
\hline Palmitoleic (16:1 n-7) & ${ }^{*} \mathrm{ND}$ & $0.30^{\mathrm{f}}$ & $0.34^{\mathrm{f}}$ & $0.52^{\mathrm{f}}$ \\
\hline Oleic $(18: 1 \mathrm{n}-9)$ & $38.01^{\mathrm{a}}$ & $42.90^{\mathrm{a}}$ & $37.77^{\mathrm{b}}$ & $27.15^{\mathrm{b}}$ \\
\hline$\Sigma \mathrm{MUFA}^{5}$ & 38.01 & 43.20 & 38.11 & 27.67 \\
\hline Linoleic (18:2 n-6) & $4.01^{\mathrm{e}}$ & $12.38^{\mathrm{c}}$ & $7.06^{\mathrm{c}}$ & $6.17^{\mathrm{c}}$ \\
\hline Linolenic (18:3n-3) & ${ }^{*} \mathrm{ND}$ & ${ }^{*} \mathrm{ND}$ & ${ }^{*} \mathrm{ND}$ & ${ }^{*} \mathrm{ND}$ \\
\hline$\Sigma$ PUFA $^{6}$ & 4.01 & 12.38 & 7.06 & 6.17 \\
\hline Trans fatty acids & $17.02^{\mathrm{d}}$ & ${ }^{*} \mathrm{ND}$ & ${ }^{*} \mathrm{ND}$ & ${ }^{*} \mathrm{ND}$ \\
\hline
\end{tabular}

${ }^{1}$ Different letter within each column indicates highly significant differences $(p<0.05) .{ }^{2}$ Values are the mean of three replicates; ${ }^{3} \mathrm{PS} / \mathrm{HOSO}=$ palm stearinhigh oleic safflower oil blends; ${ }^{4} \mathrm{SFA}=$ saturated fatty acids; ${ }^{5} \mathrm{MUFA}=$ monounsaturated fatty acids; ${ }^{6} \mathrm{PUFA}=$ polyunsaturated fatty acids; ${ }^{\dagger}$ weight percentage; ${ }^{*}$ ND: not detectable.

TABLE 4: X-ray diffraction patterns after stabilization at $25^{\circ} \mathrm{C}$ for $24 \mathrm{~h}$ of zero-trans crystallized fats produced from palm stearin-high oleic safflower oil blends compared to commercial hydrogenated shortening ${ }^{1,2}$.

\begin{tabular}{|c|c|c|c|c|c|c|c|c|}
\hline \multirow{2}{*}{ Concentration PS/HOSO ${ }^{3}(\%)$} & \multirow{2}{*}{ Rate agitation (rpm) } & \multicolumn{7}{|c|}{ Short-spacing $(\AA)^{4}$} \\
\hline & & 4.5 & 4.4 & 4.1 & 3.9 & 3.8 & 3.7 & $\mathrm{PF}^{5}$ \\
\hline \multirow{3}{*}{$50: 50$} & 1000 & $4.48^{\mathrm{a}}$ & & & & $3.81^{\mathrm{b}}$ & $3.74^{c}$ & $\beta$ \\
\hline & 2000 & $4.48^{\mathrm{a}}$ & & & & $3.81^{\mathrm{b}}$ & $3.74^{c}$ & $\beta$ \\
\hline & 3000 & $4.48^{\mathrm{a}}$ & & & & $3.81^{\mathrm{b}}$ & $3.74^{\mathrm{c}}$ & $\beta$ \\
\hline \multirow{3}{*}{$70: 30$} & 1000 & $4.54^{\mathrm{a}}$ & & & & $3.86^{\mathrm{b}}$ & $3.73^{c}$ & $\beta$ \\
\hline & 2000 & $4.54^{\mathrm{a}}$ & & & & $3.86^{\mathrm{b}}$ & $3.73^{\mathrm{c}}$ & $\beta$ \\
\hline & 3000 & $4.54^{\mathrm{a}}$ & & & & $3.86^{\mathrm{b}}$ & $3.73^{c}$ & $\beta$ \\
\hline \multirow{3}{*}{$90: 10$} & 1000 & $4.46^{\mathrm{a}}$ & & & & $3.82^{\mathrm{b}}$ & $3.66^{\mathrm{c}}$ & $\beta$ \\
\hline & 2000 & $4.46^{\mathrm{a}}$ & & & & $3.82^{\mathrm{b}}$ & $3.66^{\mathrm{c}}$ & $\beta$ \\
\hline & 3000 & $4.46^{\mathrm{a}}$ & & & & $3.82^{\mathrm{b}}$ & $3.66^{\mathrm{c}}$ & $\beta$ \\
\hline Hydrogenated commercial shortening & & - & $4.46^{\mathrm{a}}$ & $4.10^{\mathrm{b}}$ & & & $3.70^{\mathrm{c}}$ & $\beta^{\prime}$ \\
\hline
\end{tabular}

${ }^{1}$ Different letters indicate significant differences in the same row $(p<0.05) .{ }^{2}$ Values are the mean of three replicates; ${ }^{3} \mathrm{PS} / \mathrm{HOSO}=$ palm stearin-safflower high oleic oil blends; ${ }^{4} \AA$ = angstrom; ${ }^{5} \mathrm{PF}=$ polymorphic forms.

products but adverse health implications. It is known that TFA increases low-density lipoprotein (LDL) serum levels. If the blood keeps excess levels of LDL-cholesterol there is an increased risk of cardiovascular diseases [2-5].

The concentration of palmitic acid was highest in all blends of PS/HOSO. This particular saturated fatty acid has no adverse effect on serum lipoprotein profiles [35]. The most suitable blend, considering all physical properties analyzed, was the one containing 50\% PS/50\% HOSO. This particular blend had a fairly balanced FA composition (36.80\% palmitic, $42.90 \%$ oleic, and $12.38 \%$ linoleic acids), did not contain trans fatty acid isomers, and had adequate functionality as a natural vegetable shortening. Therefore, it is suitable as food ingredient for the development of new functional foods with clean labels.

3.3. Polymorphism. The patterns of XDR and polymorphic forms of fat crystals from PS and PS/HOSO blends obtained at different agitation rates and HCS are depicted in Table 4. The polymorphic forms of fat crystals are of upmost importance because they are closely related to the functional properties of shortenings [14]. Regardless of the ratio of $\mathrm{PS} / \mathrm{HOSO}$ and agitation rates, all blends tempered at $25^{\circ} \mathrm{C}$ possessed the $\beta$-crystal polymorphic forms. All PS/HOSO blends exhibited short-spacing which lied between $4.54,3.86$, and $3.73 \AA$. These spaces are distinctive and characteristic patterns for $\beta$ crystals. In our study, the tempering at $30 \pm$ $1^{\circ} \mathrm{C}$ affected the $\beta^{\prime}$ crystal formation for all samples. However, these blends presented a smooth consistency throughout 5 days' storage time. These PS/HOSO blends promoted the most stable $\beta$ polymorphic form, but the least desirable in terms of crystal size. The PS presented $\beta^{\prime}$ polymorphic form [36]. However, in our study PS exhibited a tendency to the forms $\beta \approx \beta^{\prime}$ (Table 1 ). The results obtained from the experimental blends (PS/HOSO) presented similarity to those reported by Nor Aini et al. [37]; Jeyarani and Reddy 
[13]; Mayamol et al. [14]; and Berger and Idris [38] who formulated blends of palm stearin varying the type of other complementing vegetable oils (rice bran, sesame, or soybean oil). These authors also elaborated tertiary blends palm oilpalm stearin-palm kernel olein $(40: 30: 30)$ obtaining in finished products the presence of $\beta$ polymorphic forms [37].

The HCS showed short-spacing between 4.42, 4.14, and $3.72 \AA$, characteristics of a pattern for $\beta^{\prime}$ crystal (Table 4) associated with most vegetable shortenings. It is important to mention that animal fats contain $\beta$ forms $[39,40]$. Fats with $\beta^{\prime}$ form are preferred for plastic shortenings as the crystals tend to be smaller, more uniform, and smoother, whereas the $\beta$ form imparts sandiness and graininess $[10,41]$. It is reported that a palmitic acid content above $44 \%$ in fats crystallizes in $\beta^{\prime}$ polymorphic forms desirable in margarines and shortenings [11]. However, in our study, high percentages of palmitic acid contents were observed in the PS/HOSO blends (37.8 to $57.7 \%$ ) and therefore this particular fatty acid limited the formation of high levels of $\beta^{\prime}$ crystals. The use of PS to produce the zero-trans shortenings and the proposed strategy of adding the HOSO to the blends were essential to favor the formation of $\beta$ polymorph crystals. The blend $\mathrm{PS} / \mathrm{HOSO}$ could be used in bakery products such as cookies, wheat flour tortillas, and others.

3.4. Consistency. The PS and $\mathrm{HOSO}$ ratios, speed of agitation, and storage temperatures $\left(12^{\circ} \mathrm{C}, 20^{\circ} \mathrm{C}\right.$, or $30^{\circ} \mathrm{C}$ ) affected significantly $(p<0.05)$ the consistency of the blends (Figure 1). The consistency decreased sharply with a decrease in storage temperature for all blends. When PS was added in higher amounts, the consistency decreased for all tested temperatures. Some experimental blends showed comparable consistencies compared with HCS $(150-300 \mathrm{~mm} / 10 \mathrm{~g})$ in spite of their modified fatty acid composition (high in unsaturated fatty acids with zero-TFA) (Table 3). The blends containing $50 \%, 70 \%$, or $90 \%$ of PS/HOSO had consistencies similar to hydrogenated commercial shortening. Additionally, at lower temperatures $\left(12^{\circ} \mathrm{C}\right)$, all PS/HOSO blends showed a consistency similar to commercial bakery fats, while, at higher temperature $\left(20^{\circ} \mathrm{C}\right)$, the $70 \%$ and $90 \% \mathrm{PS} / \mathrm{HOSO}$ blends exhibited consistencies similar to HCS. The consistency of $150-300 \mathrm{~mm} / 10 \mathrm{~g}$ at the temperature of $30^{\circ} \mathrm{C}$ is advantageous for use in cake manufacturing as it can retain the air incorporated during whipping and baking, and besides it is advantageous for better creaming performance $[32,42]$. The $90 \% \mathrm{PS} / 10 \% \mathrm{HOSO}$ blend stored at $30^{\circ} \mathrm{C}$ had a consistency similar to HCS, but it was not suitable as plastic fat, because of its relatively high-melting point $\left(50^{\circ} \mathrm{C}\right)$ and low IV (34.03) (Table 2). A shortening with these features imparts a waxy mouthfeel [14]. The HCS contained emulsifiers that allow crystal growth and/or polymorphic transitions which improved the consistency necessary for commercial bakery fats [43]. Furthermore, according to Mayamol et al. [14] crystallized fats manufactured from high amounts of palm stearin and low amounts of vegetable oil $(90: 10)$ tend to gradually produce grainy textured fats mainly because of their high amounts of $\beta$ crystal polymorphic forms. This undesirable texture is also attributed to the high-melting point of the palm stearin. In several instances, this crystal transformation can
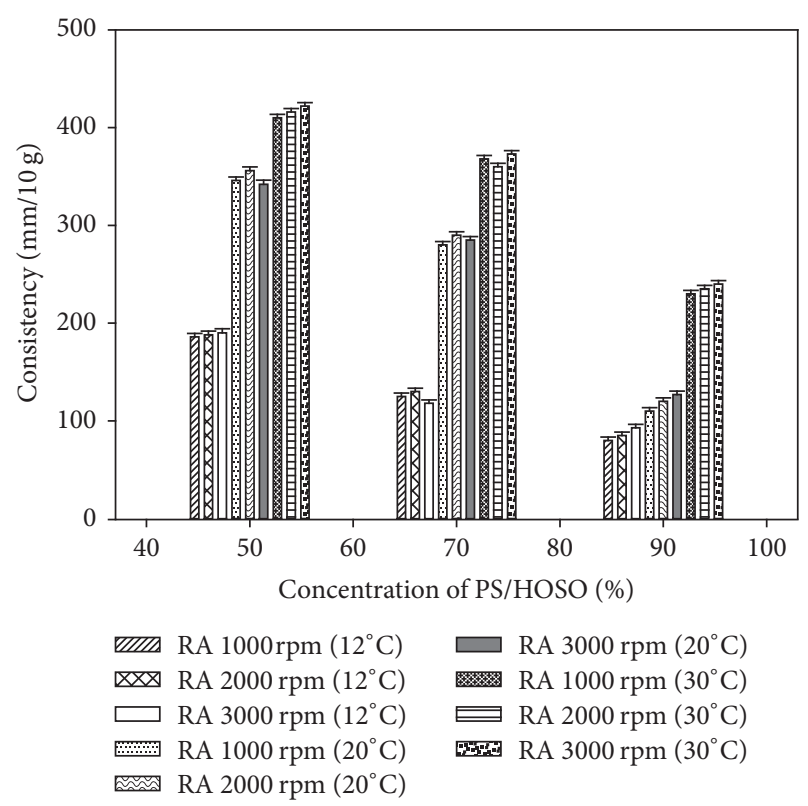

FIGURE 1: Effect of PS/HOSO (palm stearin and high oleic safflower oil) blends and rate of agitation ( $\mathrm{ra}$ ) on the consistency of zero-trans crystallized fats equilibrated at three storage temperatures.

produce oil exudation from the fat crystals with the partial coalescence of the aqueous phase and separation. Moreover, blends with high concentrations of palm stearin take longer to form fat crystals [38].

The PS is composed of high-melting triacylglycerides, which resulted in a hard consistency $(240 \mathrm{~mm} / 10 \mathrm{~g})$ at $30^{\circ} \mathrm{C}$. The mixing improved miscibility between the PS and HOSO. These PS/HOSO blends therefore are not operable over a wide range of temperatures. The blends equilibrated at low temperatures $\left(12^{\circ} \mathrm{C}\right)$ presented a hard consistency; however, counterparts equilibrated at $30^{\circ} \mathrm{C}$ exhibited a desirable softer texture. Nevertheless, blends stored at $30^{\circ} \mathrm{C}$ presented oil exudation and phase separation.

The consistency of the blend produced with 50\% PS/50\% HOSO was comparable to the PS and canola oil mixture used for a production of wheat doughs for baking [20]. The direct blending is the preferred method for formulation of zero-trans crystallized fats because it enhances the miscibility between vegetable oils and saturated fats [14]. Hence this method could assist in eliminating the posthardening phenomena, which was very notorious in PS-based fats [10]. Blends of PS with other oils (rice bran oil, canola oil, sesame oil, and soybean oil) and fats provided good plasticity and consistency $[10,12,14]$. Results herein demonstrated that the combination by direct blending of PS with HOSO could provide an array of new fat products with the desired consistency.

\section{Conclusions}

The direct blending process proposed herein indicated that the $50 \%$ PS $/ 50 \%$ HOSO blend was ideal for producing zerotrans crystallized fats because this particular blend showed 
a melting point similar to commercial bakery shortening. This specific blend system free of TFA contained the highest amounts of PUFA and MUFA. These acids are positively related to various health benefits and nutritional properties. Several of the experimental blends showed comparable consistency to hydrogenated shortenings. Thus, zero-trans crystallized plastic fats suitable for use in bakery items can be manufactured utilizing high oleic safflower oil and palm stearin. This strategy has the advantages of producing vegetable fats with enhanced functionality and well-balanced fats rich in both omega 3 and omega 6 fatty acids.

\section{Additional Points}

Practical Applications. Hydrogenated fats (trans fats) are widely used in the food industry and are highly consumed worldwide. The consumption of trans fats is related to adverse effects on serum cholesterol, triglycerides, and cardiovascular diseases. The formulation of zero-trans fats from direct mixing of vegetable sources is an alternative for the food industry. This strategy is essential to produce trans free fats that have similar characteristics to hydrogenated counterparts, with the advantage of increasing omega 3 and 6 fatty acids.

\section{Conflicts of Interest}

No conflicts of interest exist.

\section{Acknowledgments}

The senior author would like to express her sincere thanks to CONACyT for its financial support for graduate studies. The fatty acids profile analysis was performed by Dr. Luis Angel Medina Juarez at the Departamento de Investigaciones Científicas y Tecnológicas de la Universidad de Sonora (DICTUS), Hermosillo, Sonora, Mexico (http://www.dictus.uson.mx/).

\section{References}

[1] J. E. Hunter, "Dietary levels of trans-fatty acids: Basis for health concerns and industry efforts to limit use," Nutrition Research, vol. 25, no. 5, pp. 499-513, 2005.

[2] V. Dhaka, N. Gulia, K. S. Ahlawat, and B. S. Khatkar, "Trans fats-sources, health risks and alternative approach - A review," Journal of Food Science and Technology, vol. 48, no. 5, pp. 534541, 2011.

[3] D. Mozaffarian, A. Aro, and W. C. Willett, "Health effects of trans-fatty acids: Experimental and observational evidence," European Journal of Clinical Nutrition, vol. 63, pp. S5-S21, 2009.

[4] R. K. Wadhera, D. L. Steen, I. Khan, R. P. Giugliano, and J. M. Foody, "A review of low-density lipoprotein cholesterol, treatment strategies, and its impact on cardiovascular disease morbidity and mortality," Journal of Clinical Lipidology, vol. 10, no. 3, pp. 472-489, 2016.

[5] J. Hughes, F. Kee, M. O’Flaherty et al., "Modelling coronary heart disease mortality in Northern Ireland between 1987 and 2007: broader lessons for prevention.," European Journal of Preventive Cardiology, vol. 20, no. 2, pp. 310-321, 2013.
[6] D. Kromhout, J. M. Geleijnse, A. Menotti, and D. R. Jacobs Jr., "The confusion about dietary fatty acids recommendations for CHD prevention," British Journal of Nutrition, vol. 106, no. 5, pp. 627-632, 2011.

[7] E. Y. Wang, H. Wei, and J. A. Caswell, “The impact of mandatory trans fat labeling on product mix and consumer choice: A longitudinal analysis of the U.S. Market for margarine and spreads," Food Policy, vol. 64, pp. 63-81, 2016.

[8] U. S. Food and Drug Administration, "The FDA takes step to remove artificial trans fat in processed foods," June 162015 Available: (accessed 20 February 2017).

[9] J. Farmani, M. Safari, and M. Hamedi, "Application of palm olein in the production of zero-trans Iranian vanaspati through enzymatic interesterification," European Journal of Lipid Science and Technology, vol. 108, no. 8, pp. 636-643, 2006.

[10] P. N. Mayamol, C. Balachandran, T. Samuel, A. Sundaresan, and C. Arumughan, "Zero trans shortening using rice bran oil, palm oil and palm stearin through interesterification at pilot scale," International Journal of Food Science \& Technology, vol. 44, no. 1, pp. 18-28, 2009.

[11] I. N. Aini and M. S. Miskandar, "Utilization of palm oil and palm products in shortenings and margarines," European Journal of Lipid Science and Technology, vol. 109, no. 4, pp. 422-432, 2007.

[12] S. Dinç, I. Javidipour, Ö. Ö. Özbas, and A. Tekin, "Utilization of zero-trans non-interesterified and interesterified shortenings in cookie production," Journal of Food Science and Technology, vol. 51, no. 2, pp. 365-370, 2014.

[13] T. Jeyarani and S. Y. Reddy, "Preparation of Plastic Fats with Zero trans FA from Palm Oil," Journal of the American Oil Chemists' Society, vol. 80, no. 11, pp. 1107-1113, 2003.

[14] P. N. Mayamol, T. Samuel, C. Balachandran, A. Sundaresan, and C. Arumughan, "Zero-trans shortening using palm stearin and rice bran oil," Journal of the American Oil Chemists' Society, vol. 81, no. 4, pp. 407-413, 2004.

[15] K. C. Hayes and A. Pronczuk, "Replacing trans fat: The argument for palm oil with a cautionary note on interesterification," Journal of the American College of Nutrition, vol. 29, pp. 253284, 2010.

[16] M. V. Reshma, S. S. Saritha, C. Balachandran, and C. Arumughan, "Lipase catalyzed interesterification of palm stearin and rice bran oil blends for preparation of zero trans shortening with bioactive phytochemicals," Bioresource Technology, vol. 99, no. 11, pp. 5011-5019, 2008.

[17] T. Jeyarani, M. Imtiyaj Khan, and S. Khatoon, "Trans-free plastic shortenings from coconut stearin and palm stearin blends," Food Chemistry, vol. 114, no. 1, pp. 270-275, 2009.

[18] M. Sellami, H. Ghamgui, F. Frikha, Y. Gargouri, and N. Miled, "Enzymatic transesterification of palm stearin and olein blends to produce zero-trans margarine fat," BMC Biotechnology, vol. 12, article no. 48, 2012.

[19] A. R. Norizzah, C. L. Chong, C. S. Cheow, and O. Zaliha, "Effects of chemical interesterification on physicochemical properties of palm stearin and palm kernel olein blends," Food Chemistry, vol. 86, no. 2, pp. 229-235, 2004.

[20] A. Pavlovich-Abril, M. G. Salazar-García, F. J. Cinco Moroyoqui, R. Ortega Ramírez, and N. Gámez Meza, "Efectos de una mezcla de estearina de palma y aceite de canola sobre los parámetros reológicos de la masa de trigo y características del pan," Interciencia, vol. 34, pp. 577-582, 2009.

[21] R. A. Latip, Y.-Y. Lee, T.-K. Tang, E.-T. Phuah, C.-P. Tan, and O.-M. Lai, "Physicochemical properties and crystallisation 
behaviour of bakery shortening produced from stearin fraction of palm-based diacyglycerol blended with various vegetable oils," Food Chemistry, vol. 141, no. 4, pp. 3938-3946, 2013.

[22] M. Gordon, "Oils and fats: taint or flavour?" Chemistry in Britain, vol. 27, pp. 1020-1022, 1991.

[23] T. L. Mounts, K. Warner, G. R. List, W. E. Neff, and R. F. Wilson, "Low-linolenic acid soybean oil-Alternatives to frying oils," Journal of the American Oil Chemists' Society, vol. 71, no. 5, pp. 495-499, 1994.

[24] J. Roche, A. Bouniols, Z. Mouloungui, T. Barranco, and M. Cerny, "Management of environmental crop conditions to produce useful sunflower oil components," European Journal of Lipid Science and Technology, vol. 108, no. 4, pp. 287-297, 2006.

[25] F. Aladedunye and R. Przybylski, "Frying stability of high oleic sunflower oils as affected by composition of tocopherol isomers and linoleic acid content," Food Chemistry, vol. 141, no. 3, pp. 2373-2378, 2013.

[26] R. O'Brien, Fats And Oils: Formulating And Processing for Applications, CRC Press, Boca Raton NY, USA, 3rd edition, 2009.

[27] P. J. H. Jones, D. S. MacKay, V. K. Senanayake et al., "High-oleic canola oil consumption enriches LDL particle cholesteryl oleate content and reduces LDL proteoglycan binding in humans," Atherosclerosis, vol. 238, no. 2, 2015.

[28] J. Ortega-García, N. Gámez-Meza, J. A. Noriega-Rodriguez et al., "Refining of high oleic safflower oil: effect on the sterols and tocopherols content," European Food Research and Technology, vol. 223, no. 6, pp. 775-779, 2006.

[29] A. Moure, J. M. Cruz, D. Franco et al., "Natural antioxidants from residual sources," Food Chemistry, vol. 72, no. 2, pp. 145$171,2001$.

[30] American Oil Chemists Society (AOCS), Official Methods And Recommended Practices of The American Oil Chemist'S Society, AOCS Press, Champaign, Illinois, 5th edition, 2000.

[31] L. A. Medina-Juárez, N. Gámez-Meza, J. Ortega-García, J. A. Noriega-Rodriguez, and O. Angulo-Guerrero, "Trans fatty acid composition and tocopherol content in vegetable oils produced in Mexico," Journal of the American Oil Chemists' Society, vol. 77, no. 7, pp. 721-724, 2000.

[32] E. J. Pyler, Baking Science And Technology, vol. 1, 3rd edition, 1988, pp 83-127.

[33] K. Sundram, T. Thiagarajan, A. Gapor, and Y. Basiron, "Palm tocotrienols: New antioxidants for the new millennium," INFORM - International News on Fats, Oils and Related Materials, vol. 13, no. 8, pp. 634-640, 2002.

[34] M. H. A. Jahurul, I. S. M. Zaidul, N. A. Nik Norulaini et al., "Hard cocoa butter replacers from mango seed fat and palm stearin," Food Chemistry, vol. 154, pp. 323-329, 2014.

[35] M. A. French, K. Sundram, and M. T. Clandinin, "Cholesterolaemic effect of palmitic acid in relation to other dietary fatty acids," Asia Pacific Journal of Clinical Nutrition, vol. 11, supplement 7, no. s7, pp. S401-S407, 2002.

[36] S. Danthine and C. Deroanne, "Blending of Hydrogenated LowErucic Acid Rapeseed Oil, Low-Erucic Acid Rapeseed Oil, and Hydrogenated Palm Oil or Palm Oil in the Preparation of Shortenings," Journal of the American Oil Chemists' Society, vol. 80, no. 11, pp. 1069-1075, 2003.

[37] I. Nor Aini, C. H. Che Maimon, H. Hanirah, S. Zawiah, and Y. B. Che Man, “Trans-free vanaspati containing ternary blends of palm oil-palm stearin-palm olein and palm oil-palm stearinpalm kernel olein," Journal of the American Oil Chemists' Society, vol. 76, no. 5, pp. 643-648, 1999.
[38] K. G. Berger and N. A. Idris, "Formulation of zero-trans acid shortenings and margarines and other food fats with products of the oil palm," Journal of the American Oil Chemists' Society, vol. 82, no. 11, pp. 775-782, 2005.

[39] L. de Man, C. F. Shen, and J. M. de Man, "Composition, physical and textural characteristics of soft (tub) margarines," Journal of the American Oil Chemists' Society, vol. 68, no. 2, pp. 70-73, 1991.

[40] S. S. Narine and A. G. Marangoni, "Relating structure of fat crystal networks to mechanical properties: A review," Food Research International, vol. 32, no. 4, pp. 227-248, 1999.

[41] U. Shankar Shetty, Y. R. Sunki Reddy, and S. Khatoon, "Plastic fats from sal, mango and palm oil by lipase catalyzed interesterification," Journal of Food Science and Technology, vol. 51, no. 2, pp. 315-321, 2014.

[42] I. NorAini, M. S. Embong, A. Abdullah, and C. H. O. Flingoh, "Characteristics and performance of some commercial shortenings," Journal of the American Oil Chemists' Society, vol. 69, no. 9, pp. 912-916, 1992.

[43] N. Garti and J. Yano, "The roles of emulsifiers in fat crystallization," in Crystallization Processes in Fat And Lipid Systems, N. Garti and K. Sato, Eds., pp. 212-250, Marcel Dekker, New York, USA, 2001. 

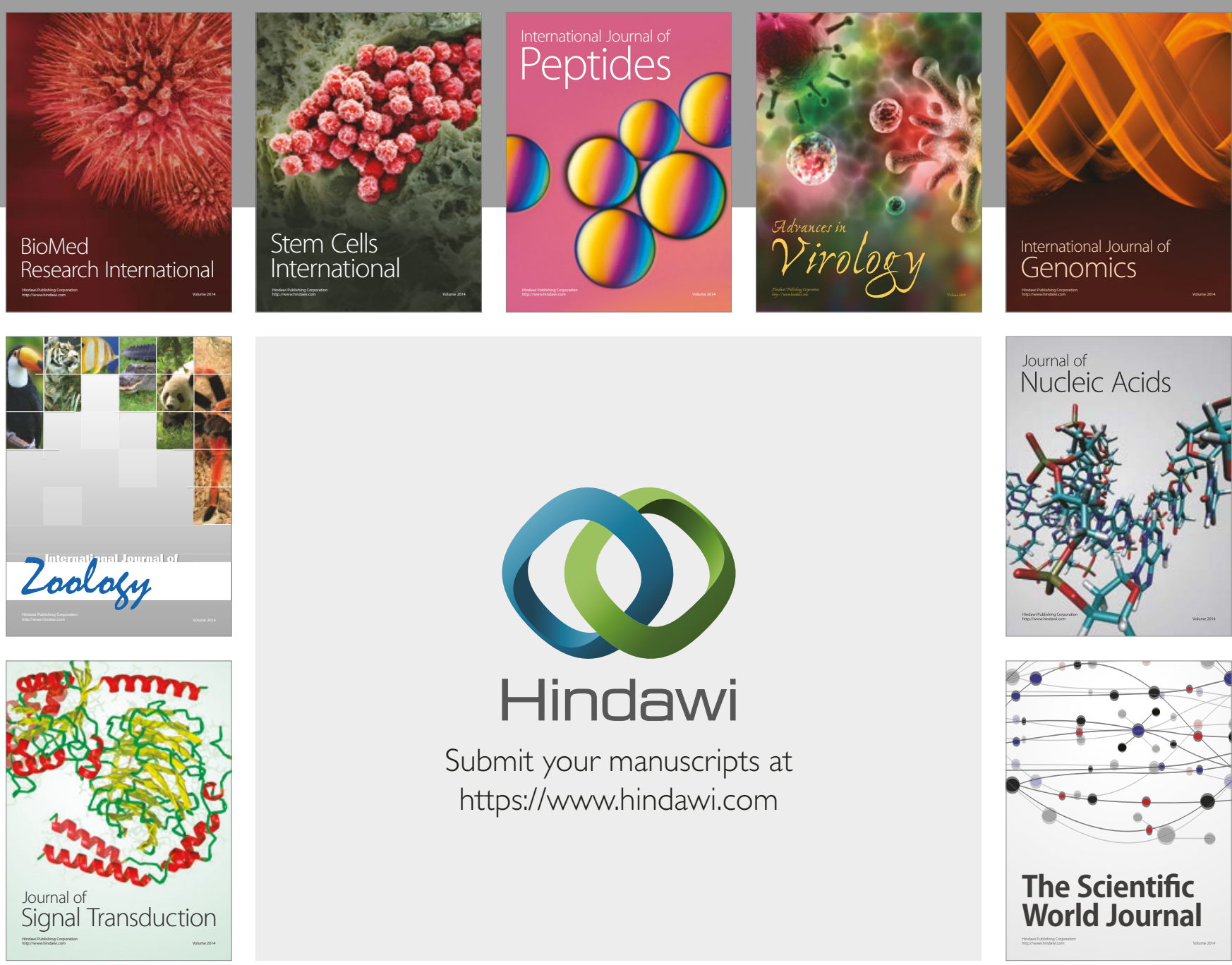

Submit your manuscripts at

https://www.hindawi.com
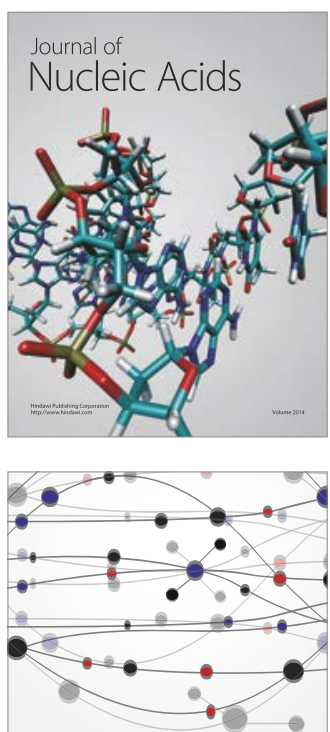

The Scientific World Journal

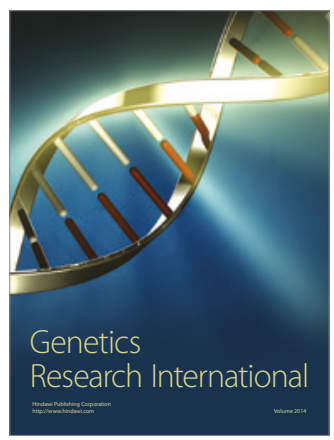

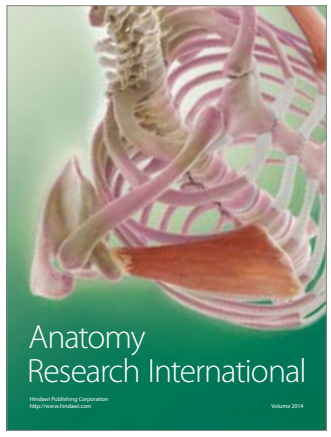

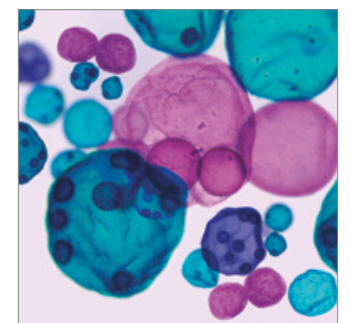

International Journal of Microbiology
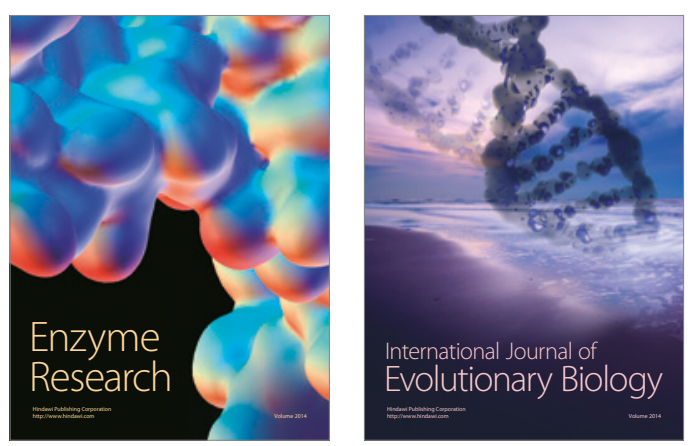
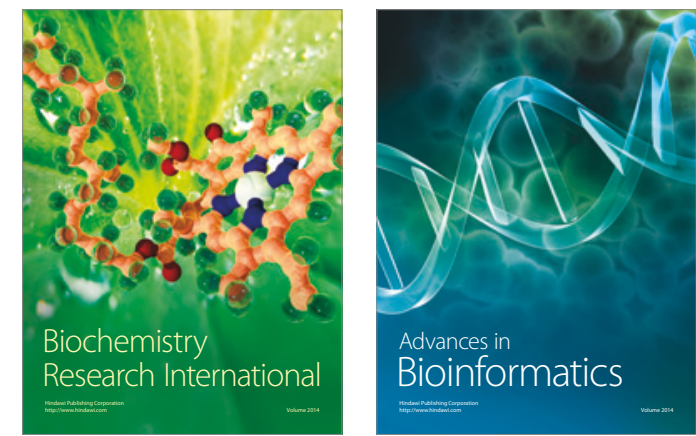

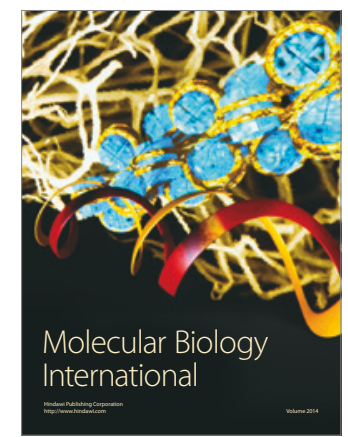

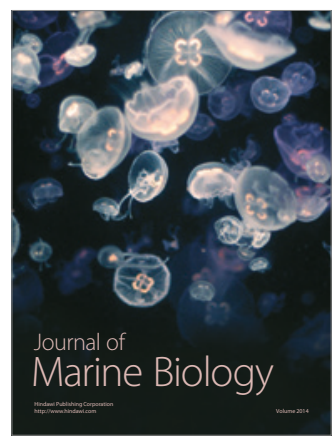

